\title{
Serological and molecular evidence of enterovirus infection in patients with end-stage dilated cardiomyopathy
}

\author{
P Muir, F Nicholson, S J Illavia, T S McNeil, J F Ajetunmobi, H Dunn, W G Starkey, \\ K N Reetoo, N R B Cary, J Parameshwar, J E Banatvala
}

\begin{abstract}
Objective-To study the relative diagnostic value of enterovirus-specific molecular biological and serological assays in patients with end-stage dilated cardiomyopathy, and to investigate the possible role of other cardiotropic viruses in dilated cardiomyopathy.

Design-Analysis of recipient myocardial tissue and serum from patients with dilated cardiomyopathy and controls undergoing cardiac transplantation for end-stage cardiac disease.
\end{abstract}

Setting-University virology department and transplantation unit.

Methods-Reverse transcriptase-polymerase chain reaction and nucleotide sequence analysis of myocardial RNA and DNA; enterovirus-specific in situ hybridisation; enterovirus-specific immunoglobulin $M$ detection.

Results-Enterovirus RNA was detected in myocardial tissue from only a small proportion of (five of 75) hearts. However, although enterovirus-specific immunoglobulin $M$ responses were detected in 22 (28\%) of 39 controls patients, a significantly higher prevalence was observed among patients with dilated cardiomyopathy (22 (56\%) of 39 patients; $P<0.005)$. All enteroviruses detected in myocardium showed greatest nucleotide sequence homology with coxsackievirus type B3. Detection of enterovirus RNA in myocardium by the polymerase chain reaction and by in situ hybridisation gave comparable results. Other potentially cardiotropic virus genomes, including human cytomegalovirus, influenzaviruses, and coronaviruses were not detected in myocardium.

Conclusion-This study found that enterovirus-specific immunoglobulin $M$ responses provided the strongest evidence of enterovirus involvement in patients with end-stage dilated cardiomyopathy. However, the high background prevalence of these responses limits their diagnostic value. The finding that enteroviruses detected in myocardium were coxsackievirus type $B 3$ accords with recent findings in patients with acute myocarditis, and indicates that this serotype is the major cardiotropic human enterovirus.

(Heart 1996;76:243-249)
Keywords: cardiomyopathy; enterovirus RNA detection; enterovirus-specific immunoglobulin $M$ responses

Although it is now well established that enteroviruses, particularly group B coxsackieviruses, are the commonest viral cause of acute myocarditis, ${ }^{1}$ their role in dilated cardiomyopathy is controversial. Serological studies showed that, compared with controls, patients with dilated cardiomyopathy had significantly higher enterovirus neutralising antibody titres than controls, ${ }^{2}$ and a higher incidence of enterovirus-specific immunoglobulin $M$ responses ${ }^{34}$ which persisted for many months or years in some patients, ${ }^{3}$ suggesting a persisting antigenic stimulus.

Although infectious virus or viral antigens cannot be detected in the myocardium of patients with dilated cardiomyopathy, molecular biological techniques have been used successfully to detect enterovirus RNA in such tissue. In studies using RNA hybridisation, enterovirus RNA was found in biopsies from $30-41 \%$ of patients with dilated cardiomyopathy and in explanted recipient myocardium from $16-29 \%$ of patients with end-stage dilated cardiomyopathy undergoing cardiac transplantation, but only rarely in control or comparison group patients. ${ }^{5-7}$ The results of some studies employing reverse transcriptionpolymerase chain reaction (PCR) support this association $^{8-10}$ whereas others do not, either failing to detect enterovirus RNA in patients with dilated cardiomyopathy, or finding enterovirus RNA in similar proportions of patients and controls (reviewed by Muir ${ }^{11}$ ).

These investigations, however, used a wide range of techniques, often of undefined sensitivity and specificity, which measure different biological indices of enterovirus infection. In addition, the classification and stage of dilated cardiomyopathy in the study population may have been variable, and control or comparison groups were selected from different clinical categories. The extent to which these factors are responsible for discrepancies in the observed association between enterovirus infection and dilated cardiomyopathy is unknown. Furthermore few studies used a range of different molecular biological and serological investigations to study the same patients and controls.

We therefore studied a single group of patients with dilated cardiomyopathy and patients with other cardiological disease serv- 
ing as controls, using enterovirus-specific immunoglobulin $M$ serology, reverse transcriptase-PCR, and in situ hybridisation assays to determine the relative diagnostic value of these assays in patients with dilated cardiomyopathy. Where enteroviruses were detected by reverse transcriptase-PCR, we determined the nucleotide sequence of representative PCR products derived from three non-overlapping regions of the viral genome in order to identify the enterovirus serotype detected and to exclude cross contamination with viral RNA or complementary DNA from other clinical samples, PCR reactions, or laboratory-propagated enterovirus strains or complementary DNA clones.

The primary site of enterovirus replication is the mucosal tissue of the gastrointestinal tract, and acute infection is frequently accompanied by viral shedding in throat secretions and stools. Because we previously showed that a high proportion of patients with dilated cardiomyopathy had persistent enterovirus-specific immunoglobulin A responses, ${ }^{3}$ we also attempted to determine whether enteroviruses persisted in intestinal mucosal tissue by examining stools for the presence of infectious enteroviruses and enteroviral RNA.

Because other viruses may also induce acute myocarditis, we also examined by PCR a number of heart samples for the presence of other potentially cardiotropic viruses such as human cytomegalovirus, ${ }^{12}$ influenzaviruses, ${ }^{13}$ and human coronaviruses. ${ }^{14} 15$

\section{Patients and methods}

PATIENTS AND SPECIMENS

Patients with end-stage cardiac or respiratory failure undergoing heart or combined heart/ lung transplantation at Papworth Hospital were included in the study. Serum was collected at the time of transplantation from 118 patients. The cause of heart failure was generally already established at the time of transplantation, and was confirmed by pathological examination of the excised heart and/or lung. Dilated cardiomyopathy was diagnosed in accordance with WHO/ISFC criteria ${ }^{16}$ in 39 patients $(33 \%)$. The remaining $79(67 \%)$ had other myocardial or pulmonary disease, including ischaemic heart disease (55 patients), cystic fibrosis (seven patients), Eisenmenger's complex (three patients), primary pulmonary hypertension (six patients), and other heart-lung disease (eight patients). Portions of excised recipient ventricular myocardium from 75 patients were snapfrozen in liquid nitrogen in theatre, and stored at $-70^{\circ} \mathrm{C}$ for PCR studies. Twenty four of these patients had dilated cardiomyopathy, and 51 had other diseases. Specimens of formalin-fixed paraffin-embedded myocardium from 22 patients (10 with dilated cardiomyopathy) were studied by in situ hybridisation. Stools were collected from an additional 44 transplant candidates attending the Transplantation Outpatient Clinic, Papworth Hospital before transplantation, and sera were collected from 38 of these patients.
ENTEROVIRUS-SPECIFIC IGM SEROLOGY

Enterovirus-specific immunoglobulin $M$ was detected in serum samples by immunoglobulin M-capture enzyme-linked immunosorbent assay (ELISA) using antigens prepared from coxsackievirus types B1-5 as described previously. ${ }^{3}$ This assay detects immunoglobulin $\mathbf{M}$ responses induced by group $B$ coxsackievirus and by other enterovirus infections.

\section{VIRUSES}

Coxsackievirus type B3, Nancy strain, was a gift from R Kandolf, Tübingen, and was propagated and titrated in Vero cells. Cytomegalovirus strain Ad169 and nine clinical isolates of influenzavirus $A$ were obtained from the Virus Diagnostic Laboratory within this department. Influenzavirus types B and $C$ and human coronaviruses types $229 \mathrm{E}$ and OC43 were obtained from the American Types and Cultures Collection. These virus stocks were used as positive controls for PCR assays.

\section{PRIMERS}

Polymerase chain reaction primers for amplification of two distinct regions of the $5^{\prime}$ nontranslated region and part of the viral polypeptide- 2 capsid-coding region of the enterovirus genome have been described previously. ${ }^{17-19}$ Primers for amplification of cytomegalovirus DNA were described by Darlington et al. ${ }^{20}$ Primers for amplification of influenzavirus RNA were designed to amplify regions of the non-structural gene segment of influenzavirus types A, B, and C, which are conserved between strains within each serotype. Primers were designed using published virus gene sequences. Primers for detection of influenzavirus types A and B were used in a single multiplex PCR. Primers for detection of human coronaviruses were designed to amplify part of the $3^{\prime}$ non-translated region of the nucleocapsid gene, which is common to all viral mRNA species as well as viral genomic RNA, based on published nucleocapsid gene sequences of human coronavirus strains $229 \mathrm{E}$ and OC43, and were also used in a single multiplex PCR. All primers used are shown in table 1. Optimal primer sequences were predicted using OLIGO 4.0 (National Biosciences). Primers were synthesised by R \& D Systems (Europe) or Pharmacia Biotech.

POLYMERASE CHAIN REACTION ASSAYS

Total RNA was extracted from $100 \mu$ l of virus stock or stool filtrate, or from about $100 \mathrm{mg}$ portions of cryopreserved myocardium using RNAzol B (Cinna Biotecx, Houston, Texas) as described previously, ${ }^{17}$ and tested for the presence of enterovirus, influenzavirus, and human coronavirus RNA by reverse transcriptase-PCR. Nested and semi-nested reverse transcriptase-PCR assays for detection of enterovirus RNA have been described previously. ${ }^{1819}$ All myocardial samples were examined using both primer sets which amplify regions of the $5^{\prime}$ non-translated region of the enterovirus genome. Those in which enterovirus RNA was detected by one or both 
Table 1 Primers for polymerase chain reaction amplification of viral nucleic acid

\begin{tabular}{|c|c|c|c|c|}
\hline Target sequence & $\begin{array}{l}\text { Nucleotide } \\
\text { positions } \\
\text { of target } \\
\text { sequence }\end{array}$ & $\begin{array}{l}\text { Primer } \\
\text { designation }\end{array}$ & Primer sequence $\left(5^{\prime}\right.$ to $\left.3^{\prime}\right) \dagger$ & $\begin{array}{l}\text { Nucleotide } \\
\text { positions } \\
\text { of primer }\end{array}$ \\
\hline \multirow[t]{4}{*}{ Enterovirus 5'NTR } & \multirow[t]{4}{*}{ 417-645 } & EVU1 & GGTGYGAAGAGYCTAYTGAG & \multirow{9}{*}{$\begin{array}{l}417-436 \\
645-628 \\
456-473 \\
602-583 \\
375-363 \\
63-82 \\
377-363 \\
180-195 \\
299-283\end{array}$} \\
\hline & & EVD1 & CACYGGRTGGCYAATCCA & \\
\hline & & EVU2 & CCCCTGAATGCGGCTAAT & \\
\hline & & EVD2 & ATTGTCACCATAAGCAGCCA & \\
\hline \multirow[t]{5}{*}{ Enterovirus 5'NTR } & \multirow[t]{5}{*}{ 63-377 } & EVD3 & CAGGCCGCCAACG & \\
\hline & & EVU3 & CGGTACCTTTGTGCGCCTGT & \\
\hline & & EVD4 & GGCAGGCCGCCAACG & \\
\hline & & EVU5 & CCCCGGACTGAGTATC & \\
\hline & & EVD5 & AGTGCTGAGCGAAACAC & \\
\hline \multirow[t]{3}{*}{ Enterovirus VP2 } & \multirow[t]{3}{*}{$1177-1485$} & EVU6 & SCDGGDTGGTGGTGGAA & \multirow{15}{*}{$\begin{array}{l}1177-1190 \\
1485-1467 \\
1225-1249 \\
81558-81583 \\
81707-81683 \\
130-147 \\
266-246 \\
274-296 \\
468-449 \\
322-342 \\
572-552 \\
1453-1463 \\
1628-1609 \\
1544-1742 \\
1773-1752\end{array}$} \\
\hline & & EVD6 & YACYCCCATRCCRGCATT & \\
\hline & & EVU7 & TGGRCARAAYATGCARTAYCACTAC & \\
\hline Cytomegalovirus Ad169 & 81558-81707 & gB1 & GTCGACGGTGGAGATACTGCTGAGG & \\
\hline & & gB2 & GAGGACAACGAAATCCTGTTGGGCA & \\
\hline Influenzavirus A & $130-266$ & IFAU1 & GACTTCGCCGAGATCAGA & \\
\hline & & IFAD1 & GGTCATTTTAAGTGCCTCATC & \\
\hline Influenzavirus B & $274-468$ & IFBU1 & GAGAGAAAAGCAATTGGGGTAAA & \\
\hline nonstructural gene & & IFBD1 & ATCGACATTTTCCGGCTCTT & \\
\hline Influenzavirus C & $322-572$ & IFCU1 & ACATAGCACCAATTGGGCAAA & \\
\hline nonstructural gene & & IFCDI & GGCCACTTGTTTAGCGATGAG & \\
\hline Human coronavirus $229 \mathrm{E}$ & $1453-1628$ & HCV 229EU1 & ATGATCCCTTGTTTGGCTTGA & \\
\hline Nucleocapsid gene 3NTR & & $\mathrm{HCV} 229 \mathrm{EDI}$ & CTCTTCCATTGTTGGCTCGTC & \\
\hline Human coronavirus $\mathrm{OC} 43$ & \multirow[t]{2}{*}{$1544-1773$} & $\mathrm{HCV} \mathrm{OC43U1}$ & TGTCGGCATCTGGTGGTAA & \\
\hline Nucleocapsid gene 3NTR & & $\mathrm{HCV}$ OC43DI & ACTGGGTGGTAACTTAACATG & \\
\hline
\end{tabular}

*Nucleotide base positions based on those of published sequences (see text).

†Redundant base codes: $Y=C$ or $T ; R=A$ or $G ; S=C$ or $G ; D=A, G$ or $T$.

NTR, non-translated region; VP, viral polypeptide.

of these primer sets were examined further using primers to amplify part of the viral polypeptide-2 capsid-coding region of the genome. Reverse transcriptase-PCR assays for detection of influenzavirus and human coronavirus RNA employed the same reagents and methods, but used annealing temperatures, cycle numbers, and magnesium ion concentrations optimised for each primer pair as shown in table 2. Both upstream and downstream primers were included in reverse transcription reactions for influenzavirus $P C R$ assays to allow detection of both viral genomic and message sense RNA. Total DNA was extracted from about $100 \mathrm{mg}$ portions of myocardium and tested for the presence of cytomegalovirus DNA by PCR as described elsewhere. ${ }^{20}$ Enterovirus RNA was extracted from stool samples and analysed by reverse transcriptase-
PCR using primers EVU2 and EVD2 (table 1) followed by Southern blot hybridisation as described previously. ${ }^{17}$ Precautions were adopted to avoid false positive results caused by PCR contamination, as described previously. ${ }^{17} 18$

SOUTHERN BLOT HYBRIDISATION

Southern blot hybridisation was used to confirm the identity of cytomegalovirus, influenzavirus, and human coronavirus PCR products. Southern blotting was performed as described previously, ${ }^{17}$ and hybridisation was performed using digoxygenin-11-deoxy-uridine triphosphate-labelled PCR products derived from reference virus strains as hybridisation probes and a digoxygenin detection kit (Boehringer Mannheim) according to the manufacturer's protocol.

Table 2 Primers and polymerase chain reaction amplification conditions for detection of viral nucleic acids

\begin{tabular}{|c|c|c|c|c|c|c|c|c|c|}
\hline \multirow[b]{2}{*}{ Target } & \multirow[b]{2}{*}{$\begin{array}{l}\text { Reverse } \\
\text { transcription } \\
\text { primer }\end{array}$} & \multirow[b]{2}{*}{$\begin{array}{l}\text { Primers } \\
\text { (size of } \\
\text { product) }\end{array}$} & \multicolumn{4}{|l|}{ First PCR } & \multicolumn{3}{|c|}{ Nested PCR } \\
\hline & & & $\begin{array}{l}\mathrm{MgCl}_{2} \\
\text { concen- } \\
\text { tration }\end{array}$ & $\begin{array}{l}\text { Annealing } \\
\text { tempera- } \\
\text { ture }\end{array}$ & $\begin{array}{l}\text { Cycle } \\
\text { number }\end{array}$ & $\begin{array}{l}\text { Primers } \\
\text { (sizeo } \\
\text { product) }\end{array}$ & $\begin{array}{l}\mathrm{MgCl}_{2} \\
\text { concen- } \\
\text { tration }\end{array}$ & $\begin{array}{l}\text { Annealing } \\
\text { tempera- } \\
\text { ture }\end{array}$ & $\begin{array}{l}\text { Cycle } \\
\text { number }\end{array}$ \\
\hline $\begin{array}{l}\text { Enterovirus } \\
\text { 5NTR } \\
\text { nt 417-645 } \\
\text { Enterovirus }\end{array}$ & EVD1 & $\begin{array}{l}\text { EVU1 and EVD1 } \\
(299 \mathrm{bp})\end{array}$ & $2.0 \mathrm{mM}$ & $50 \mathrm{C}$ & 30 & $\begin{array}{l}\text { EVD2 and } \\
\text { EVD2 (147 bp) }\end{array}$ & $1.8 \mathrm{mM}$ & $52 \mathrm{C}$ & 25 \\
\hline $\begin{array}{l}\text { 5NTR } \\
\text { nt 63-377 } \\
\text { Enterovirus }\end{array}$ & EVD3 & $\begin{array}{l}\text { EVU3 and EVD4 } \\
(315 \mathrm{bp})\end{array}$ & $2.0 \mathrm{mM}$ & $58 \mathrm{C}$ & 40 & $\begin{array}{l}\text { EVU5 and } \\
\text { EVD5 (120 bp) }\end{array}$ & $2 \cdot 4 \mathrm{mM}$ & $49 \mathrm{C}$ & 15 \\
\hline $\begin{array}{l}\text { VP2 } 2 \text { capsid } \\
\text { nt } 1177-1485 \\
\text { HCMV }\end{array}$ & EVD6 & $\begin{array}{l}\text { EVU6 and EVD6 } \\
(309 \mathrm{bp})\end{array}$ & $2.6 \mathrm{mM}$ & $55 \mathrm{C}$ & 40 & $\begin{array}{l}\text { EVU7 and } \\
\text { EVD6 (261 bp) }\end{array}$ & $1.4 \mathrm{mM}$ & $50 \mathrm{C}$ & 15 \\
\hline $\begin{array}{l}\text { glycoprotein } \\
\text { B gene } \\
\text { Influenzavirus }\end{array}$ & - & $\begin{array}{l}\text { gB1 and gB2 } \\
\text { (117 bp) }\end{array}$ & $2.0 \mathrm{mM}$ & $55 \mathrm{C}$ & 40 & - & - & - & - \\
\hline $\begin{array}{l}\text { A and B } \\
\text { nonstructural } \\
\text { genes }\end{array}$ & $\begin{array}{l}\text { IFAU1 and IFAD1 } \\
\text { IFBU1 and IFBD1 }\end{array}$ & $\begin{array}{l}\text { IFAU1 and } \\
\text { IFAD1 (137 bp) } \\
\text { IFBU1 and }\end{array}$ & $1.2 \mathrm{mM}$ & $51 \mathrm{C}$ & 40 & - & - & - & - \\
\hline $\begin{array}{l}\text { Influenzavirus C } \\
\text { nonstructural gene } \\
\text { Human }\end{array}$ & IFCU1 and IFCD1 & $\begin{array}{l}\text { IFBD1 (195 bp) } \\
\text { IFCU1 and } \\
\text { IFCD1 ( } 251 \text { bp) }\end{array}$ & $1.2 \mathrm{mM}$ & $51 \mathrm{C}$ & 40 & - & - & - & - \\
\hline $\begin{array}{l}\text { coronavirus strains } \\
229 \mathrm{E} \text { and OC43 } \\
\text { nucleocapsid genes }\end{array}$ & $\begin{array}{l}\text { 229EU1 and 229ED1 } \\
\text { OC43U1 and OC43D1 }\end{array}$ & $\begin{array}{l}\text { 229EU1 and } \\
\text { 229ED1 (176 bp) } \\
\text { OC4331 and } \\
\text { OC43D1 (230 bp) }\end{array}$ & $1.0 \mathrm{mM}$ & $51 \mathrm{C}$ & 40 & - & - & - & - \\
\hline
\end{tabular}

bp, base pairs; mM, millimolar; NTR, non-translated region; VP, viral polypeptide. 
Table 3 Results of virus serology and polymerase chain reaction in patients with dilated cardiomyopathy and controls

\begin{tabular}{|c|c|c|c|c|c|c|}
\hline \multirow[b]{2}{*}{ Patient group } & \multirow[b]{2}{*}{$\begin{array}{l}\text { Enterovirus- } \\
\text { specific IgM }\end{array}$} & \multicolumn{2}{|c|}{ Enterovirus PCR } & \multirow[b]{2}{*}{$\begin{array}{l}H C M V \\
P C R\end{array}$} & \multirow{2}{*}{$\begin{array}{l}\text { Influenzavirus } \\
A, B \text { and } \\
C P C R\end{array}$} & \multirow{2}{*}{$\begin{array}{l}\text { Human } \\
\text { coronavirus } 229 E \\
\text { and OC43 PCR }\end{array}$} \\
\hline & & $\begin{array}{l}\text { EVU1/D1/ } \\
U 2 / D 2\end{array}$ & $\begin{array}{l}E V D 3 / U 3 / \\
D 4 / U 5 / D 5\end{array}$ & & & \\
\hline $\begin{array}{l}\text { DCM } \\
\text { Controls } \\
\text { P value }\end{array}$ & $\begin{array}{l}23 / 43(53.5 \%) \\
23 / 79(29 \%) \\
P<0.02\end{array}$ & $\begin{array}{l}1 / 25(4 \%) \\
4 / 51(7 \cdot 8 \%) \\
\text { NS }\end{array}$ & $\begin{array}{l}1 / 24(4 \cdot 2 \%) \\
4 / 51(7 \cdot 8 \%) \\
\text { NS }\end{array}$ & $\begin{array}{l}0 / 9 \\
0 / 13 \\
\text { NS }\end{array}$ & $\begin{array}{l}0 / 8 \\
0 / 14 \\
\text { NS }\end{array}$ & $\begin{array}{l}0 / 8 \\
0 / 14 \\
\text { NS }\end{array}$ \\
\hline
\end{tabular}

DCM, dilated cardiomyopathy; IgM, immunoglobulin M; PCR, polymerase chain reaction.

\section{POLYMERASE CHAIN REACTION SENSITIVITY DETERMINATIONS}

The sensitivity of PCR assays was determined by analysis of limiting dilutions of synthetic DNA or RNA targets. Cytomegalovirus DNA PCR targets were generated by PCR amplification of cytomegalovirus strain Ad169 DNA and quantified by ultraviolet spectrophotometry. RNA virus PCR targets were obtained by cloning PCR products derived from amplification of RNA prepared from virus stocks into a transcription vector using the pGEM-T Vector System II (Promega UK) according to manufacturer's protocol. Synthetic RNA transcripts were generated using T7 or SP6 RNA polymerase (Promega UK), treated with DNase to remove vector DNA, purified by extraction with RNAzol B, and quantified by ultraviolet spectrophotometry.

\section{NUCLEOTIDE SEQUENCE ANALYSIS}

The nucleotide sequence of biotinylated nested PCR products generated using primers EVU2 and EVD2 was determined by direct solidphase sequencing as described previously. ${ }^{19}$ Other enterovirus PCR products to be sequenced were cloned in pGEM-T vector, and sequenced using fluorescein-labelled $\mathrm{T} 7$ or SP6 RNA polymerase promoter-specific sequencing primers with an Autoread sequencing kit and ALF DNA sequencer (Pharmacia). Nucleotide sequences were compared with published sequences of standard enterovirus strains using DNASIS to determine the serotypic identity of enteroviruses detected.

IN SITU HYBRIDISATION

Replicate sections of formalin-fixed recipient myocardium ( $5 \mu \mathrm{m}$ thick) were examined for the presence of enterovirus RNA by in situ hybridisation using digoxygenin-labelled enterovirus-specific and control probes as described previously. ${ }^{19}$

\section{VIRUS ISOLATION}

Enterovirus isolation from stool samples was attempted by inoculation of stool filtrate into Vero, monkey kidney, and human embryo fibroblast cell cultures, which were observed for cytopathic effect for two, three, and four weeks respectively before being regarded as negative.

\section{Results}

ENTEROVIRUS-SPECIFIC IGM RESPONSES

Enterovirus-specific immunoglobulin $M$ was detected in $22(56 \%)$ of 39 patients with dilated cardiomyopathy taken at or around the time of transplantation, but in only 22 $(28 \%)$ of 79 patients with other diagnoses (table 3). There was a statistically significant difference in prevalence of enterovirus-specific immunoglobulin $M$ between patients with dilated cardiomyopathy and controls ( $\mathbf{P}<0.005 ; \chi^{2}$ with Yates's correction). Most immunoglobulin $M$ responses were multitypic, that is, reactive with antigens derived from multiple group B coxsackievirus serotypes. There was no difference in the level of enterovirus-specific immunoglobulin $M$ as determined from net optical density values between immunoglobulin $M$ positive patients with dilated cardiomyopathy and immunoglobulin $\mathrm{M}$ positive patients with other diagnoses (not shown).

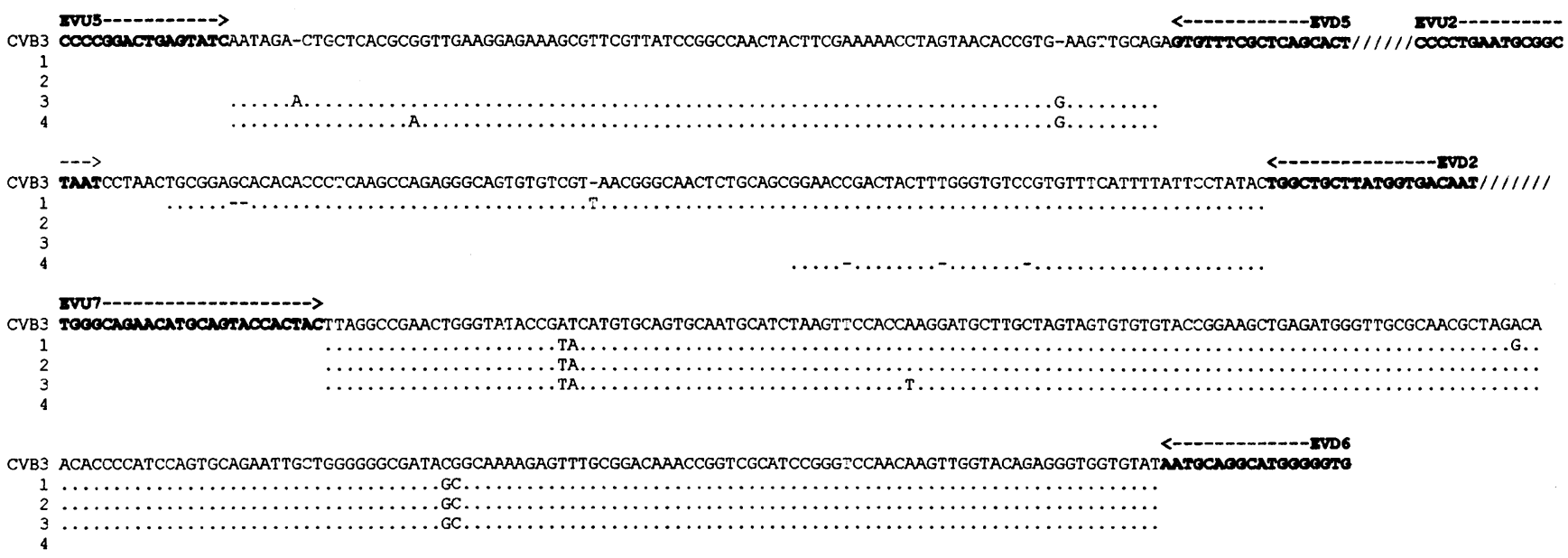

Figure 1 Alignment of nucleotide sequences of enterovirus polymerase chain reaction products derived from myocardium of four patients (patients 1-4; see table 4) with the published coxsackievirus type B3 sequence. Primer recognition sequences are shown in bold face. $A$ dot (.) indicates an identical base to that of coxsackievirus type B3. A dash (-) indicates a relative deletion. 

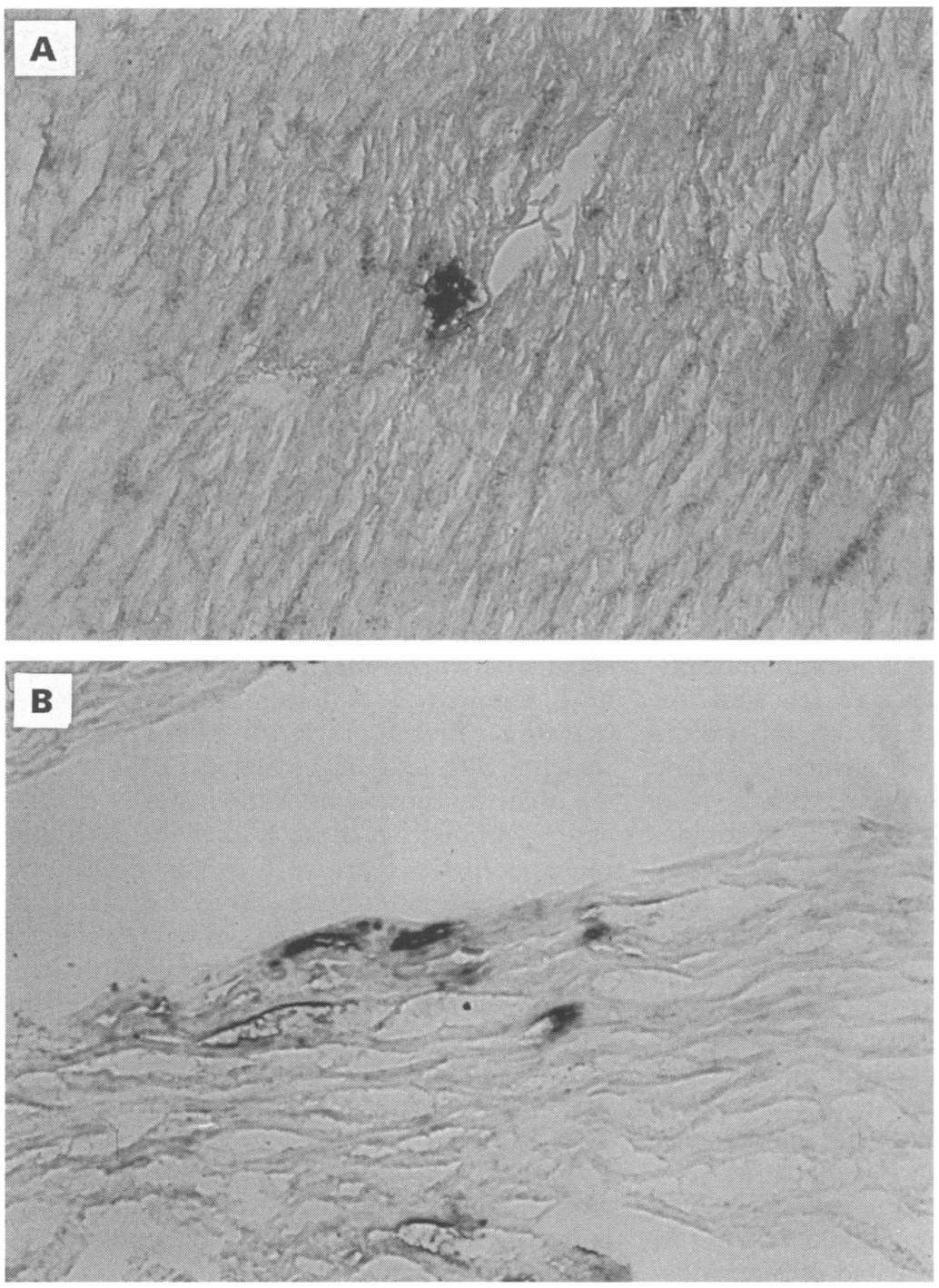

Figure 2 Visualisation of enterovirus $R$ NA by in situ hybridisation in myocardium from patients $6(A)$ and $9(B)$ (see table 4 for patient details).

POLYMERASE CHAIN REACTION DETECTION OF VIRAL GENOMES IN MYOCARDIUM

In limiting dilution experiments, PCR assays for all viruses being investigated were found to detect as few as 10-100 synthetic RNA or DNA target molecules. Enterovirus RNA was

Table 4 Results of enterovirus-specific polymerase chain reaction, in situ hybridisation, and immunoglobulin $M$ serology in selected patients and controls

\begin{tabular}{rllll}
\hline Patient & Patient group & $\begin{array}{l}\text { Enterovirus } \\
\text { PCR }\end{array}$ & $\begin{array}{l}\text { Enterovirus } \\
\text { in situ hybridisation }\end{array}$ & $\begin{array}{l}\text { Enterovirus- } \\
\text { specific IgM }\end{array}$ \\
\hline 1 & Control & + & + & + \\
2 & Control & + & + & - \\
3 & Control & + & + & + \\
4 & DCM & + & - & - \\
5 & Control & - & - & + \\
6 & DCM & - & + & - \\
7 & DCM & - & - & - \\
8 & Control & - & - & - \\
9 & Control & - & + & - \\
10 & Control & - & - & + \\
11 & DCM & - & - & + \\
12 & DCM & - & - & + \\
13 & DCM & - & - & + \\
14 & DCM & - & + & - \\
15 & Control & - & - & + \\
16 & Control & - & - & - \\
17 & DCM & - & - & - \\
18 & DCM & - & - & - \\
19 & DCM & - & + & + \\
20 & Control & - & - & + \\
21 & Control & - & - & + \\
22 & Control & - & - & + \\
\hline
\end{tabular}

DCM, dilated cardiomyopathy; IgM, immunoglobulin M; PCR, polymerase chain reaction. detected by reverse transcriptase-PCR using primers EVUI/EVD1 and nested primers EVU2/EVD2 in myocardium from one $(4 \cdot 2 \%)$ of 24 patients with dilated cardiomyopathy, and in four $(7 \cdot 8 \%)$ of 51 patients with other disease (not significant; $\chi^{2}$ analysis) (table 3). There was insufficient material from one enterovirus-positive sample for further analysis. A second PCR assay using primers EVD3/EVU3/EVD4 and nested primers EVU5/EVD5 was used as a confirmatory assay to test the remaining 74 samples. There was $100 \%$ concordance between results of these two assays. The third primer set which amplifies within the viral polypeptide- 2 capsid-coding region also detected enterovirus RNA in all four samples found positive with the first two PCR assays. Nucleotide sequence analysis of PCR products indicated that all enteroviruses sequences detected were unique, and therefore extremely unlikely to represent PCR contamination, but all shared their greatest genetic homology with coxsackievirus B3 (fig 1). There was no discernible correlation between detection of enterovirus RNA and the presence of enterovirus-specific immunoglobulin $M$; only two of the five patients in whom enterovirus RNA was detected in myocardium had detectable enterovirus-specific immunoglobulin $M$ responses at the time of transplantation. Cytomegalovirus, influenzaviruses, and human coronaviruses were not detected in myocardial tissue from patients with dilated cardiomyopathy or from controls (table 3 ).

\section{IN SITU HYBRIDISATION}

To assess the relation between results of reverse transcriptase PCR and in situ hybridisation, selected PCR positive and negative and patients with dilated cardiomyopathy and controls were studied blind by in situ hybridisation. Enterovirus RNA was detected by in situ hybridisation in myocardium from two of 10 patients with dilated cardiomyopathy and five of 12 patients from the comparison group. The results of enterovirus PCR, in situ hybridisation, and immunoglobulin $M$ serology for these patients is shown in table 4 . Results of in situ hybridisation for patients 6 and 9 are also shown in fig 2. Agreement between results of enterovirus PCR and in situ hybridisation was $77 \%$; with a chance corrected measure of agreement ( $\kappa$ coefficient) of $0 \cdot 74$, indicating substantial agreement. ${ }^{21}$ There was no correlation between results of in situ hybridisation and patient group or enterovirus-specific immunoglobulin M status.

\section{DETECTION OF ENTEROVIRUSES IN STOOL} SAMPLES

Enteroviruses were not detected by cell culture in stool samples from 44 cardiac transplant candidates or by reverse transcriptase-PCR in 16 patients. Eighteen of these patients had dilated cardiomyopathy, of whom eight $(44 \%)$ had enterovirus-specific immunoglobulin $M$ responses. The remaining 26 had other diagnoses, and five $(19 \%)$ of 
these patients had enterovirus-specific immunoglobulin $M$ responses.

\section{Discussion}

We used a range of serological and molecular diagnostic techniques to investigate the association of enterovirus infection with dilated cardiomyopathy. Enterovirus RNA was detected by reverse transcriptase-PCR in myocardium in only a small proportion of patients in this study $(6.7 \%)$, there being no difference between patients with dilated cardiomyopathy and the comparison group. However, the most striking finding was the significant difference in the prevalence of enterovirus-specific immunoglobulin $\mathrm{M}$ responses between patients with dilated cardiomyopathy and controls at cardiac transplantation. Although this assay provided the strongest evidence of association, immunoglobulin $\mathrm{M}$ responses were detected relatively frequently in controls. This probably reflects the ubiquity of these viruses, which circulate among the general population with a wide range in seasonal prevalence. In addition, immunoglobulin $M$ responses may frequently be detectable for six months or longer after acute infection. ${ }^{22}$ This limits the utility of enterovirus-specific immunoglobulin $M$ testing for the diagnosis of enterovirus-induced heart disease. There was no correlation between the presence of enterovirus-specific immunoglobulin $\mathrm{M}$ and the presence of enterovirus RNA in myocardium, indicating that these are independent markers of enterovirus infection.

A significantly higher prevalence of enterovirus-specific immunoglobulin $M$ responses in patients with dilated cardiomyopathy than in healthy persons has previously been reported. ${ }^{34}$ We previously showed that immunoglobulin $M$ responses frequently persisted for many months or years in patients with dilated cardiomyopathy. ${ }^{3}$ The mechanism underlying persistence of enterovirus-specific immunoglobulin $M$ responses in the absence of detectable viral antigens in myocardium remains to be determined. Possible explanations include the persistence of enteroviruses in a replicative form at other anatomical sites. Although we examined stools for enteroviruses, none was detected. Liljeqvist $e t a l^{23}$ also failed to detect enteroviruses in stools by culture after acidification to dissociate antibody-complexed virus. While this suggests that enteroviruses do not persist in the gastrointestinal tract of patients with dilated cardiomyopathy, examination of mucosal tissue obtained post mortem would be helpful in excluding this. Enterovirus persistence has been reported at other anatomical sites, and skeletal muscle, lymph nodes, and leucocytes should also be investigated. Alternatively, immune responses may persist beyond clearance of virus infection, as has been demonstrated in mice experimentally infected with lymphocytic choriomeningitis virus. ${ }^{24}$ Ongoing antigenic stimulation may result from persistence of immune complexes, molecular mimicry, or the induction of idiotype-anti-idiotype responses.

Discrepancies in the rates of enterovirus
RNA detection in patients with dilated cardiomyopathy and controls reported in previous studies may be due to differences in patient demography, stage of disease, or a difference in the sensitivity, specificity, or reliability of detection methods. However, we have shown that our assays can not only detect a wide range of enterovirus serotypes in clinical specimens, ${ }^{1718}$ including myocardial tissue from patients with acute myocarditis, ${ }^{19}$ but also that our assays are able to detect as few as 10-100 genome copies. The low rate of enterovirus RNA detection in myocardium of patients with dilated cardiomyopathy reported here is therefore unlikely to be due to insensitivity of our PCR assays, and is more likely due to the fact that, unlike most other studies, all patients studied here were undergoing transplantation for end-stage disease, by which stage enterovirus-infected myocytes may have been eliminated. A lower enterovirus RNA detection rate has previously been reported in patients with end-stage dilated cardiomyopathy than in those with earlier stages of disease, ${ }^{67}$ although in those studies the detection rate was higher than we found in this study. Alternatively, enterovirus-induced dilated cardiomyopathy may have a different clinical course from other causes of dilated cardiomyopathy, ${ }^{2526}$ and may be under-represented among those requiring transplantation.

To compare the diagnostic potential of PCR and in situ hybridisation, we studied myocardium from selected patients by both techniques. Although the numbers studied were small, there was substantial agreement, indicating that these different detection methods provide comparable results. Some discrepancies were observed, but this may have been due to differing assay sensitivity or specificity, sampling errors resulting from uneven distribution of virus infected cells in myocardium, or differences in the integrity of RNA in cryopreserved tissue used for PCR and formalin-fixed paraffin embedded tissue used for in situ hybridisation.

Nucleotide sequence analysis showed that viruses detected in myocardium were coxsackievirus type B3, a finding that we and others have previously reported in patients with myocarditis and dilated cardiomyopathy. ${ }^{9}{ }^{1019}$ If the predominance of coxsackievirus type B3 among patients with myocarditis and dilated cardiomyopathy is confirmed by further study in larger numbers, this may provide the impetus for development of a coxsackievirus type B3 vaccine to protect against this commonest viral agent of myocardial disease. Further study should therefore focus upon this enterovirus serotype to elucidate the molecular basis of cardiotropism and pathogenesis. ${ }^{27} 28$

Although only a few hearts were examined, cytomegalovirus, influenzavirus, and human coronavirus genomes were not detected by PCR in myocardial tissue from either patient group. These PCR assays were found to be sensitive in limiting dilution assays, but we were not able to evaluate the sensitivity and specificity of these assays for the detection of viral nucleic acid in myocardial tissue. Our 
negative findings must therefore be interpreted with caution. Patients at earlier stages of disease should also be investigated. Other potentially cardiotropic viruses that might also be considered include the adenoviruses, which have recently been shown to be an important cause of acute myocarditis and cardiomyopathy in childhood. ${ }^{29}$

Our results indicate that it may be difficult to establish a virological diagnosis in patients with end-stage dilated cardiomyopathy by the currently available techniques. Endomyocardial biopsies from patients with recent onset disease are likely to be more useful. However, this requires invasive sampling procedures as well as considerable molecular biological expertise, and may be subject to sampling error because of focal distribution of enterovirus-infected myocytes. More specific serological assays are therefore desirable. A coxsackievirus type B3-specific immunoassay may provide a more specific marker of enterovirus-induced heart disease.

Our serological results support the accumulated data from numerous studies that used different molecular and serological techniques. This suggests that enterovirus infection is involved in the pathogenesis of dilated cardiomyopathy. Further study is required to define the true incidence of enterovirusinduced dilated cardiomyopathy and to understand its pathogenesis. There is also a need for further evaluation, standardisation, and quality assurance of methods for enterovirus diagnosis in patients with dilated cardiomyopathy, particularly PCR methods, which continue to give rise to conflicting data from different laboratories. This should involve wider use of confirmatory assays with alternative primers, and nucleotide sequencing to confirm PCR specificity. A commercial enterovirus PCR test (Roche Diagnostic Systems) which has been validated for the detection of enterovirus RNA in cerebrospinal fluid from patients with infections of the central nervous system ${ }^{30}$ may improve standardisation, if its performance on testing myocardial tissue is found to be satisfactory.

This study was funded by grants 90/92, PG92122 and PG94145 from the British Heart Foundation, grant 1575 from the Royal Society, and grants from the Philip Fleming the Royal Society, and grants from the Philip Fleming Charitable Trust and the Special Trustees of St Thomas'
Hospital. FN is the recipient of a training fellowship from the Hospital. FN is the recipient of a training fellowship from the
Special Trustees of St Thomas' Hospital. KNR is the recipient Special Trustees of St Thomas' Hospital. KNR is the recipient
of a scholarship from the Association of Commonwealth of a scholarship from the Association of Commonwealth
Universities. We thank Dr TG Wreghitt, Department of Universities. We thank Dr TG Wreghitt, Department of
Microbiology, Addenbrooke's Hospital, Cambridge for providMicrobiology, Addenbrooke's Hospital, Cambridge for provid-
ing additional serum samples for this project, Ms Noreen ing additional serum samples for this project, Ms Noreen
Caine, Research and Development Department, Papworth Caine, Research and Development Department, Papworth
Hospital for providing patient details, and Dr S Chinn, Department of Public Health Medicine, Guy's and St Thomas' Hospital Trust, London, for statistical advice.

1 Grist NR, Reid D. Epidemiology of viral infections of the heart. In: Banatvala JE, ed. Viral infections of the heart. London: Edward Arnold, 1993:23-31.

2 Cambridge G, MacArthur CGC, Waterson AP, Goodwin $\mathrm{JF}$, Oakley CM. Antibodies to coxsackie B viruses in primary congestive cardiomyopathy. Br Heart $\mathcal{f} 1979 ; 41$ : 692-6.

3 Muir P, Nicholson F, Tilzey AJ, Signy M, English TAH, Banatvala JE. Chronic relapsing pericarditis and dilated cardiomyopathy: serological evidence of persistent enterovirus infection. Lancet 1989;i:804-7.

4 Keeling PJ, Lukaszyk A, Poloniecki J, Caforio AL, Davies MJ, Booth JC, et al. A prospective case-control study of antibodies to coxsackie B virus in idiopathic dilated cardiomyopathy. $\mathcal{F}$ Am Coll Cardiol 1994;23:593-8.
5 Archard LC, Freeke C, Richardson P, Meany B, Olsen E, Morgan-Capner $P$, et al. Persistence of enterovirus RNA in dilated cardiomyopathy: a progression from dilated cardiomyopathy. In: Schultheiss H-P, ed. New concepts in viral heart disease. Berlin: Springer-Verlag, 1988:349-62.

6 Bowles NE, Rose ML, Taylor P, Banner NR, MorganCapner P, Cunningham L, et al. End-stage dilated cardiomyopathy. Persistence of enterovirus RNA in myocardium at cardiac transplantation and lack of immune response. Circulation 1989;80:1128-36.

7 Kandolf R, Canu A, Klingel K, Kirschner P, Schönke H, Mertsching $R$, et al. Molecular studies on enteroviral heart disease. In: Brinton MA, Heinz FX, eds. New aspects of positive-strand RNA viruses. Washington DC: American Society of Microbiology, 1990; 340-8.

8 Schwaiger A, Umlauft F, Weyrer K, Larcher C, Lyons J, Mühlberger V, et al. Detection of enterovirus ribonucleic acid in myocardial biopsies from patients with idiopathic dilated cardiomyopathy by polymerase chain reaction. Am Heart $\mathcal{f} 1993 ; 126: 406-10$.

9 Kämmerer U, Kunkel B, Korn K. Nested polymerase chain reaction for specific detection and rapid identification of reaction for specific detection and rapid identification of
human picornaviruses. $¥$ Clin Microbiol 1994;32:285-91.

human picornaviruses. $\mathcal{f}$ Clin Microbiol 1994;32:285-91.
10 Khan M, Why H, Richardson P, Archard LC. Nucleotide sequencing of polymerase chain reaction products shows the presence of Coxsackie-B3 virus in endomyocardial the presence of Coxsackie-B3 virus in endomyocardial biopsies from patients with myocarditis or dilate
diomyopathy. Biochem Soc Trans 1994;22:176S.

11 Muir P. Enteroviruses and heart disease. Br $¥$ Biomed Sci 1993;50:258-71.

12 Schönian U, Crombach M, Maisch B. Does CMV infection play a role in myocarditis? New aspects from in-situ hybridisation. Eur Heart f 1991;12 suppl D:65-8.

13 Landsdown ABG. Viral infections and diseases of the heart. Prog Med Virol 1978;24:70-113.

14 Riski H, Hovi T. Coronavirus infections of man associated with diseases other than the common cold. $\mathcal{F}$ Med Virol 1980;6:259-65.

15 Alexander LK, Small JD, Edwards S, Baric RS. An experimental model for dilated cardiomyopathy after rabbit coronavirus infection. $\mathcal{f}$ Infect Dis 1992;166:978-85.

16 Report of the International Society and Federation of Cardiology/World Health Organisation. Task force on the definition and classification of cardiomyopathies. $\mathrm{Br}$ Heart $\mathcal{f} 1980 ; 44: 672-3$.

17 Muir P, Nicholson F, Jhetam M, Neogi S, Banatvala JE. Rapid diagnosis of enterovirus infection by magnetic bead extraction and polymerase chain reaction detection of enterovirus RNA in clinical specimens. $\mathcal{F}$ Clin Microbiol of enterovirus R

18 Nicholson F, Meetoo G, Aiyar S, Banatvala JE, Muir P. Detection of enterovirus RNA in clinical samples by Detection of enterovirus RNA in clinical samples by
nested polymerase chain reaction for rapid diagnosis of nested polymerase chain reaction for rapid diagnosis

19 Nicholson F, Illavia SJ, Ajetunmobi JF, Shackleton EA, Li M, Starkey WG, et al. Molecular detection and serotypic analysis of enterovirus RNA in myocardium of patients with acute myocarditis. Br Heart $\mathcal{F}$ 1995;74:522-7.

20 Darlington J, Super M, Patel K, Grundy JE, Griffiths PD, Emery VC. Use of the polymerase chain reaction to analyse sequence variation within a major neutralizing epitope of glycoprotein B (gp58) in clinical isolates of human cytomegalovirus. $\mathcal{F}$ Gen Virol 1991;72:1985-9.

21 Landis JR, Koch GC. The measurement of observer agreement for categorical data. Biometrics 1977;33:159-74.

22 Muir P, Nicholson F, Banatvala JE, Bingley PJ. Coxsackie B virus and postviral fatigue syndrome. $\mathrm{Br} M e d \mathcal{F} 1991 ; 302$ : 658-9.

23 Liljeqvist J-Å, Bergström T, Holmström S, Samuelson A, Yousef GE, Waagstein $\mathrm{F}$, et al. Failure to demonstrate enterovirus aetiology in Swedish patients with dilated cardiomyopathy. F Med Virol 1993;39:6-10.

24 Slifka MS, Matloubian M, Ahmed R. Bone marrow is a major site of long-term antibody production after acute viral infection. $\mathcal{F}$ Virol 1995;69:1895-902.

25 Why HJ, Meany BT, Richardson PJ, Olsen EG, Bowles $\mathrm{NE}$, Cunningham L, et al. Clinical and prognostic significance of detection of enteroviral RNA in the myoicance of detection of enteroviral RNA in the myo-
cardium of patients with myocarditis with myocarditis or cardium of patients with myocarditis with myocarditis
dilated cardiomyopathy. Circulation 1994;89:2582-9.

26 Figulla HR, Stille-Siegener M, Mall G, Heim A, Kreuzer H. Myocardial enterovirus infection with left ventricular dysfunction: a benign disease compared with idiopathic dysfunction: a benign disease compared with idiopathic dilated carc $1170-5$.

27 Zhang HY, Yousef GE, Cunningham L, Blake NW, OuYang X, Bayston TA, et al. Attenuation of a reactivated cardiovirulent coxsackievirus B3: the 5'-nontranslated region does not contain major attenuation determinants. $\mathcal{F}$ Med Virol 1993;41:129-37.

$28 \mathrm{Tu}$ Z, Chapman NM, Hufnagel G, Tracy S, Romero JR, Barry WH, et al. The cardiovirulent phenotype of coxsackievirus B3 is determined at a single site in the genomic $5^{\prime}$ nontranslated region. $f$ Virol 1995;69: 4607-18.

29 Martin AB, Webber S, Fricker FJ, Jaffe R, Demmler G, Kearney $\mathrm{D}$, et al. Acute myocarditis. Rapid diagnosis by polymerase chain reaction in children. Circulation 1994; 90:330-9.

30 Rotbart HA, Sawyer MH, Fast S, Lewinski C, Murphy N, Keyser EF, et al. Diagnosis of enteroviral meningitis by using polymerase chain reaction with a colorimetric microwell detection assay. $\mathcal{F}$ Clin Microbiol 1994;32: 2590-2. 